\section{Holdninger, ferdigheter og kunnskap i palliativ medisin}

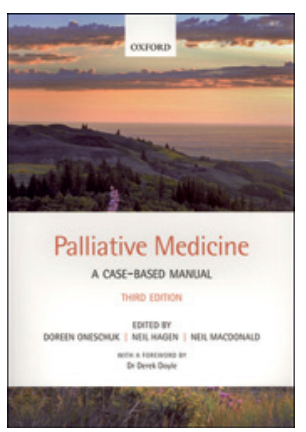

\begin{abstract}
Doreen Oneschuk, Neil Hagen,
\end{abstract}
Neil MacDonald, red.

Palliative medicine

A case-based manual. 3. utg. $411 \mathrm{~s}$, tab, ill.

Oxford: Oxford University Press, 2012.

Pris GBP 33

ISBN 987-0-19-969414-3

Målet er å gi en innføring i fagfeltet palliativ medisin - først og fremst for studenter og yngre leger. Boken er skrevet av en stor forfattergruppe fra Canada med et tydelig kanadisk perspektiv. Imidlertid er dette ikke så farlig siden Canada er et av de fremste foregangslandene innen feltet. Det norske perspektivet kan lett tilføyes ved å konsultere Nasjonalt handlingsprogram med retningslinjer for palliasjon i kreftomsorgen.

Forfatterne ønsker å presentere palliativ medisin på en lett tilgjengelig måte. Som i de første to utgavene gjør de dette ved hjelp av kasuistikker, der et mer eller mindre karakteristisk pasientforløp danner den røde tråden for problembasert læring. I denne håndboken dekker de et meget vidt spekter av palliativ medisin og etterlater ingen tvil om at palliasjon er mye mer enn smertebehandling. Viktige momenter er at fysiske plager kun lar seg behandle på tilfredsstillende måte når de plasseres i den psykiske, sosiale og åndelig-eksistensielle konteksten med en multidisiplinær tilnærming. Innholdet dekker alle symptomer som innbefattes av det mest basale verktøyet for symptomkartlegging, Edmonton Symptom Assessment System (ESAS), men også et helt grunnleggende tema som kommunikasjon. Samtidig tar forfatterne opp nokså spesifikke symptomer som malign tarmobstruksjon, sårbehandling, urogenitale plager og symptomer relatert til munnen. Spesielt må jeg nevne kapitlene om palliative problemstillinger rundt barn, pasienter på intensivavdelinger og pasienter med ikke-maligne sykdommer som hjertesvikt, terminal nyresvikt eller hiv/aids.

I hvert kapittel starter forfatterne med å definere to til fire læringsmål med henblikk på holdninger, ferdigheter og kunnskap. Kasuistikken brukes til å utfordre leseren med spørsmål, som i de aller fleste tilfeller besvares på en kompakt og lett forståelig måte. Et stort antall figurer og tabeller bidrar til en oversiktlig presentasjon av stoffet. Illustrasjonene av sykdommer i munnhulen kunne med fordel vært trykt i farger.

Denne nye utgaven innfrir forventningen om å være oppdatert med den nyeste kunnskapen. Dette illustrerer spesielt kapitlet om anoreksi-kakeksi-syndromet, som ble definert av European Palliative Care Research Collaborative så sent som i 2011.

Jeg mener at denne håndboken ikke bare passer for de yngste legene, men også for mer viderekomne kolleger. Palliativ medisin har kun en kort tradisjon som del av medisinutdanningen og er nærmest fraværende i spesialistutdanningen i Norge. Jeg anbefaler boken sterkt for alle leger i primær- eller spesialisthelsetjenesten som har ansvar for pasienter med behov for lindrende behandling, enten daglig eller mer sjelden, og med maligne eller ikke-maligne grunnsykdommer. Den vil sikkert kunne få plass i mange bokhyller på legekontorer, sykehusavdelinger, på sykehjem med eller uten lindrende enhet - eller på nattbordet slik som forfatterne ønsker.

\section{Hartwig Kørner}

Gastrokirurgisk avdeling

Stavanger universitetssjukehus

og

Regionalt kompetansesenter i lindrende behandling Helse Vest

Haukeland universitetssykehus

\section{Din mørke e-personlighet}

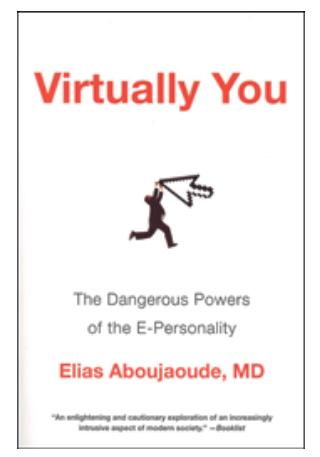

Elias Aboujaoude

\section{Virtually you}

The dangerous power of the e-personality. 349 s. New York, NY: W.W. Norton, 2012.

Pris USD 18

ISBN 978-0-393-34054-9

Hva får personer til å lyve om eget utseende på en sjekkeside på nett, utvikle kjærlighetsforhold til andre virtuelle personer selv om man er gift, eller spille seg til fant på et nettkasino? Internett i seg selv, ifølge den amerikanske psykiateren Elias Aboujaoude. På over 300 sider argumenterer han utrettelig for at Internett ikke bare bringer frem det verste i folk, men kan bidra til at vi utvikler personlighetsforstyrrelser.

De 12 ordrike kapitlene er i hovedsak delt inn etter kjente personlighetsforstyrrelser i det amerikanske diagnosesystemet DSMIV (Diagnostic and Statistical Manual of Mental Disorders). Basert på freudiansk personlighetsteori trekker han frem eksempler på at vi i stor grad styres av drifter når vi er på nett. Vi opptrer narsissistisk eller grandiost, går i barndommen, mangler impulskontroll og blir avhengige av spill og sex. Han dokumenterer med pasienthistorier fra egen praksis og eksempler han kjenner fra mediene, og kun $i$ liten grad med relevante forskningsresultater. Alle eksemplene er amerikanske. Selv om Internett er globalt, gjør dette dessverre relevansen for norske lesere mindre.

Ved å benytte oss av ulike tjenester på Internett, som sjekkesider og nettkasinoer, utvikler vi et virtuelt jeg - en e-personlighet som ikke samsvarer med personligheten vi har i det virkelige liv. På Internett, i e-post, chat og SMS uttrykker vi oss annerledes og handler uten de samme moralske imperativene som regulerer oss for øvrig. Etter hvert blir grensene mellom de forskjellige personlighetene uklare, og resultatet kan bli at vi utvikler personlighetsforstyrrelser, mener Aboujaoude. Han er overbevist om det skjer et fundamentalt psykologisk skift i oss når vi logger oss på nett.

Fra et medievitenskapelig ståsted vil boken fort kategoriseres som teknologideterminisme - udokumentert frykt og forventninger som oppstår i møte med ny teknologi. Jeg jobber daglig med å utvikle nettbaserte tjenester for leger og forholder meg til alle de positive sidene ved den teknologiske utviklingen. Perspektivet er så negativt at det til slutt blir vanskelig å ta forfatteren på alvor. Alt det nyttige som vi til daglig benytter Internett og digitale medier til, vendes til det negative - selv e-postkommunikasjon mellom ansatte i bedrifter. Forfatterens tolkning av eksemplene han trekker frem, er også provoserende moraliserende og dømmende.

Samtidig ser jeg gjennom egen bruk av sosiale medier daglig uttrykk for noen av tendensene som forfatteren beskriver. Diskusjonene blir mindre nyanserte, folk våger mer skjult bak pseudonym og avatarer enn de gjør i det virkelige liv. Etiske grenser utfordres. Derfor er det synd at boken blir for unyansert til at jeg klarer å gjøre den selvransakelsen av egen virtuell personlighet som forfatteren oppfordrer til. Teknologien er verken ond eller god - den er det vi velger å bruke den til.

Boken kan være aktuell for alle som bruker mye tid på digitale medier, og for leger som møter pasienter som gjør det.

\section{Stine Bjerkestrand}

Tidsskriftet 